\title{
Pola Komplikasi Kronis Penderita Diabetes Melitus Tipe 2 Rawat Inap di Bagian Penyakit Dalam RS. Dr. M. Djamil Padang Januari 2011 - Desember 2012
}

\author{
Dwi Amelisa Edwina ${ }^{1}$, Asman Manaf $^{2}$, Efrida $^{3}$
}

\begin{abstract}
Abstrak
Diabetes Melitus (DM) merupakan suatu kelompok penyakit metabolik dengan karakteristik hiperglikemia. DM tipe 2 adalah yang paling sering ditemukan. Komplikasi kronis DM tipe 2 yaitu mikrovaskular dan makrovaskular yang dapat menurunkan kualitas hidup penderita. Tujuan penelitian ini adalah untuk memperoleh gambaran tentang insidensi penderita DM tipe 2 dengan komplikasi kronis. Penelitian deskriptif ini dilakukan dengan mengambil data pada rekam medik penderita DM tipe 2 dengan komplikasi kronis yang dirawat inap di bagian Penyakit Dalam RS.Dr. M. Djamil, Padang Januari 2011-Desember 2012. Penelitian dilakukan dari Februari 2013-April 2013 di bagian rekam medik RS. Dr. M. Djamil Padang. Data didapatkan sebanyak 261 pasien, dari jumlah tersebut didapatkan 197 pasien memiliki komplikasi kronis DM tipe 2. Data dikategorikan berdasarkan jenis komplikasi makrovaskular dan mikrovaskular. Hasil penelitian menunjukkan bahwa penderita dengan komplikasi kronis makrovaskular $(66,5 \%)$ dan mikrovaskular (81,7\%). Terdapat perubahan insidensi dalam dua tahun yaitu dari tahun 2011 dengan 2012. Komplikasi kronis yang paling sering terjadi adalah nefropati diabetik $(42,6 \%)$ pada perempuan $<60$ tahun.
\end{abstract}

Kata kunci: diabetes melitus, komplikasi mikrovaskular, komplikasi makrovaskular

\begin{abstract}
Diabetes mellitus is a group of metabolic diseases with characterized by hyperglycemia. Type 2 diabetes is the most common disease in the world. Chronic complications of type 2 diabetes are microvascular and macrovascular complications that can reduce the quality of life of patients. The objective of this study was to obtain a picture of the incidence of type 2 diabetic chronic complications. This descriptive study was conducted by taking medical record data of hospitalized type 2 diabetic patients with chronic complications inInternal Medicine Department Dr. M. Djamil hospital, Padang on January 2011-December 2012. The study was conducted from February 2013-April 2013 at the hospital medical record Dr. M. Djamil, Padang. This study was conducted on 261 patients, from that number 197 patients have chronic complications of type 2 diabetes mellitus. Data were categorized by type of macrovascular and microvascular complications. The results showed that patients with chronic complications of macrovascular (66,5\%) and microvascular (81,7\%). There is a change in incidence from 2011 to 2012. The most common of chronic complications is diabetic nephropathy (42.6\%). Chronic microvascular and macrovascular complications are different incidence in two years, the most common is diabetic nephropathy which often occurs in women $<60$ years.
\end{abstract}

Keyword: diabetes mellitus, microvascular complication, macrovacular complication.

Affiliasi penulis: 1. Pendiidikan Dokter FK UNAND (Fakultas Kedokteran Universitas Andalas Padang), 2. Bagian Penyakit Dalam FK UNAND/ RSUP Dr. M. Djamil Padang, 3. Bagian Patologi Klinik/ RSUP Dr. M. Djamil Padang

Korespondensi : Dwi Amelisa Edwina, E-

mail:amelisadwi@gmail.com, Telp: 082381344194

\section{PENDAHULUAN}

Diabetes Melitus (DM) adalah penyakit kronis, yang terjadi ketika pankreas tidak menghasilkan insulin atau ketika tubuh tidak dapat secara efektif menggunakan insulin yang 
dihasilkan.Hal ini menyebabkan peningkatan konsentrasi glukosa dalam darah (hiperglikemia). Angka kejadian DM yang semakin meningkat di beberapa negara berkembang dilatar belakangi oleh meningkatnya kemakmuran di negara tersebut yang selalu menjadi sorotan dunia. Pendapatan perkapita yang meningkat dan perubahan gaya hidup di kotakota besar juga memiliki peranan penting dalam peningkatan prevalensi penyakit ini. ${ }^{1}$

Jumlah penyandang DM di dunia pada tahun 2011 mencapai 336 juta jiwa dan diprediksi akan terus bertambah menjadi 350 juta jiwa pada tahun 2020. DM termasuk penyakit terbanyak di Asia, tahun 2006 diperkirakan 89 juta penduduk Asia menderita DM. Prevalensi DM di Asia Tenggara sebanyak 46 juta jiwa dan diperkirakan meningkat menjadi 119 juta jiwa. Berdasarkan pola pertambahan penduduk saat ini diperkirakan jumlah penyandang DM tahun 2010 sebanyak 306 juta jiwa, di negara-negara ASEAN 19,4 juta jiwa pada tahun 2010 . $^{2}$

Menurut data World Health Organization (WHO), jumlah penyandang DM di Indonesia merupakan yang terbanyak setelah India, China, dan Amerika Serikat. WHO memprediksi kenaikan jumlah penyandang DM di Indonesia dari 8,4 juta jiwa pada tahun 2000 menjadi sekitar 21,3 juta jiwa pada tahun 2030. International Diabetes Federation (IDF) pada tahun 2009, memprediksi kenaikan jumlah penyandang DM dari 7,0 juta jiwa pada tahun 2009 menjadi 12,0 juta jiwa pada tahun 2030. Meskipun terdapat perbedaan angka prevalensi, laporan keduanya menunjukkan adanya peningkatan jumlah penyandang DM sebanyak 2-3 kali lipat pada tahun $2030 .^{3}$

DM digolongkan atas DM tergantung insulin (DM tipe 1) dan DM tidak tergantung insulin (DM tipe 2). DM tipe 2 yang tidak ditangani dengan baik akan menimbulkan berbagai komplikasi yaitu komplikasi akut dan komplikasi kronik. Komplikasi kronis DM tipe 2 dapat berupa komplikasi mikrovaskular dan makrovaskular yang dapat menurunkan kualitas hidup penderita. Penyebab utama kematian penyandang DM tipe 2 adalah komplikasi makrovaskular. Komplikasi makrovaskular melibatkan pembuluh darah besar yaitu pembuluh darah koroner, pembuluh darah otak dan pembuluh darah perifer. Mikrovaskular merupakan lesi spesifik diabetes yang menyerang kapiler dan arteriola retina (retinopati diabetik), glomerulus ginjal (nefropati diabetik) dan saraf-saraf perifer (neuropati diabetik). ${ }^{4}$

Penelitian ini bertujuan untuk melihat pola komplikasi kronis penderita DM tipe 2 yang dirawat inap di Bagian Penyakit Dalam RS. Dr. M. Djamil Padang Januari 2011 - Desember 2012.

\section{METODE}

Penelitian ini merupakan penelitian deskriptif dengan menggunakan data sekunder dari status pasien yaitu data rekam medik penderita DM tipe 2 yang dirawat inap di bagian Penyakit Dalam RS. Dr. M. Djamil Padang Januari 2011 - Desember 2012 dengan komplikasi kronis pada catatan rekam medis.

Pengolahan data meliputi kegiatan penghitungan angka komplikasi yang muncul pada seorang pasien berdasarkan data rekam medik kemudian disajikan dalam bentuk tabel. Pada penyusunan hasil penelitian ini data yang akan dijumlah dan dipersenkan berdasarkan kejadian komplikasi yang muncul. Jika seseorang menderita lebih dari satu jenis komplikasi (misal: menderita makrovaskular dan mikrovaskular sekaligus), seseorang tersebut akan tercatat lebih dari satu kali, yaitu pada hitungan manapun yang mencakup komplikasi yang dideritanya.

\section{HASIL}

Penderita DM tipe 2 yang dirawat inap di Bagian Penyakit Dalam RS. Dr. M. Djamil Padang antara Januari 2011-Desember 2012, didapatkan jumlah populasi sebanyak 261 orang. Dari populasi tersebut ditemukan penderita DM tipe 2 dengan komplikasi kronik (sampel) sebanyak 197 orang, terbanyak dialami oleh perempuan (63\%) dengan usia $<60$ tahun $(74 \%)$.

\section{Karakteristik Umum Subjek Penelitian}

Tabel 1. Distribusi Penderita DM Tipe 2 dengan Komplikasi Kronis Menurut Usia dan Jenis Kelamin

\begin{tabular}{ccccccc}
\hline $\begin{array}{c}\text { Usia } \\
\text { (tahun) }\end{array}$ & Laki-laki & Perempuan & \multicolumn{2}{c}{ Jumlah } \\
\hline & $\mathrm{n}$ & $\%$ & $\mathrm{n}$ & $\%$ & $\mathrm{n}$ & $\%$ \\
\hline$<60$ & 47 & 65 & 92 & 74 & 139 & 71 \\
\hline$\geq 60$ & 25 & 35 & 33 & 26 & 58 & 29 \\
\hline Jumlah & 72 & 100 & 125 & 100 & 197 & 100 \\
\hline
\end{tabular}


Pada tabel 1 dapat dilihat bahwa penderita DM tipe 2 dengan komplikasi kronis terbanyak adalah usia<60 tahun (71\%). Pada usia tersebut terdapat penderita komplikasi kronis laki-laki sebesar $65 \%$ dan perempuan $74 \%$.

\section{Data Penelitian}

Tabel2. Distribusi Frekuensi Penderita DM Tipe dengan Komplikasi Kronis tahun 2011-2012

\begin{tabular}{cccc}
\hline & Makrovaskular & Mikrovaskular & $\begin{array}{c}\text { Makro dan } \\
\text { Mikro }\end{array}$ \\
\hline (2011) Ya & $35(17,8 \%)$ & $38(19,3 \%)$ & $24(12,2 \%)$ \\
Tidak & $14(7,1 \%)$ & $11(5,6 \%)$ & $25(12,7 \%)$ \\
$(2012)$ Ya & $96(48,7 \%)$ & $123(62,4 \%)$ & $71(36 \%)$ \\
Tidak & $52(26,4 \%)$ & $25(12,7 \%)$ & $77(39 \%)$ \\
\hline Jumlah & $197(100 \%)$ & $197(100 \%)$ & $197(100 \%)$ \\
\hline Ket: makro = makrovaskular & & \\
mikro $=$ mikrovaskular & &
\end{tabular}

Pada tabel 2 dapat dilihat bahwa jumlah penderita DM tipe 2 dengan komplikasi kronis adalah 197 orang, diketahui dari tahun 2011 hingga 2012 penderita dengan komplikasi kronis makrovaskular sebanyak 131 dari 197 orang (66,5\%), penderita yang memiliki komplikasi mikrovaskular sebanyak 161 dari 197 orang $(81,7 \%)$ dan yang memiliki makrovaskular dan mikrovaskular 95 dari 197 orang (48,2\%).

Tabel 3. Distribusi Frekuensi Jenis Komplikasi Kronis Penderita DM Tipe 2 Januari 2011 - Desember 2012

\begin{tabular}{cccc}
\hline $\begin{array}{c}\text { Jenis } \\
\text { komplikasi }\end{array}$ & Pengidap & Tidak & Jumlah \\
\hline PJK & $65(33 \%)$ & $132(67 \%)$ & 197 \\
PPDO & $37(19 \%)$ & $160(81 \%)$ & 197 \\
PPDP & $59(30 \%)$ & $138(70 \%)$ & 197 \\
RD & $74(37,6 \%)$ & $123(62,4 \%)$ & 197 \\
NfD & $84(42,6 \%)$ & $113(57,4 \%)$ & 197 \\
ND & $46(23,4 \%)$ & $151(76,6 \%)$ & 197 \\
\hline Ket: & & &
\end{tabular}

PJK: penyakit jantung koroner,

PPDO: penyakit pembuluh darah otak,

PPDP: penyakit pembuluh darah perifer,

RD: retinopati diabetik,

$\mathrm{NfD}$ : nefropati diabetik,

ND: neuropati diabetik.

Pada tabel 3 dapat dilihat bahwa insidensi komplikasi kronis terbanyak pada penderita DM tipe 2 dengan komplikasi kronis adalah nefropati diabetik $(42,6 \%)$, selanjutnya disusul dengan komplikasi retinopati diabetik $(37,6 \%)$, penyakit jantung koroner (33\%), penyakit pembuluh darah perifer (30\%), neuropati diabetik (23,4\%), dan terakhir adalah penyakit pembuluh darah otak (19\%).

Tabel 4. Distribusi Frekuensi Perbandingan Insidensi Jenis Komplikasi Kronis Makrovaskular Penderita DM Tipe 2 Tahun 2011 dan 2012

\begin{tabular}{|c|c|c|c|}
\hline & \multicolumn{3}{|c|}{ Komplikasi Makrovaskular } \\
\hline & PJK & PPDO & PPDP \\
\hline$(2011) \mathrm{Ya}$ & $12(6,1 \%)$ & $10(5,1 \%)$ & $22(11,2 \%)$ \\
\hline Tidak & $37(18,8 \%)$ & $39(19,8 \%)$ & $27(13,7 \%)$ \\
\hline (2012) Ya & $53(26,9 \%)$ & $27(13,7 \%)$ & $37(18,8 \%)$ \\
\hline Tidak & $95(48,2 \%)$ & $121(61,4 \%)$ & $111(56,3 \%)$ \\
\hline Jumlah & $197(100 \%)$ & $197(100 \%)$ & $197(100 \%)$ \\
\hline
\end{tabular}

Tabel 5. Distribusi Frekuensi Perbandingan Insidensi Jenis Komplikasi Kronis Mikrovaskular Penderita DM Tipe 2 Tahun 2011 dan 2012

\begin{tabular}{clll}
\hline & \multicolumn{3}{c}{ Komplikasi Mikrovaskular } \\
\hline & RD & NfD & ND \\
\hline (2011) Ya & $16(8,1 \%)$ & $24(12,2 \%)$ & $13(6,6 \%)$ \\
Tidak & $33(16,8 \%)$ & $25(12,7 \%)$ & $36(18,3 \%)$ \\
$(2012)$ Ya & $58(29,4 \%)$ & $60(30,5 \%)$ & $33(16,8 \%)$ \\
Tidak & $90(45,7 \%)$ & $88(44,7 \%)$ & $115(58,4 \%)$ \\
\hline Jumlah & $197(100 \%)$ & $197(100 \%)$ & $197(100 \%)$ \\
\hline
\end{tabular}

Pada tabel 4 dan tabel 5 diatas dapat dilihat bahwa insidensi komplikasi kronis DM tipe 2 berbeda antara tahun 2011 dengan tahun 2012. Didapatkan total penderita dengan komplikasi kronis DM tipe 2 rawat inap di bagian Penyakit Dalam pada tahun 2011 sebanyak 49 orang dengan 35 orang penderita komplikasi kronis makrovaskular, diantaranya penyakit jantung koroner $6,1 \%$ (12 orang), penyakit pembuluh darah otak $5,1 \%$ (10 orang), penyakit pembuluh darah perifer $11,2 \%$ (22 orang), dan 38 orang penderita komplikasi kronis mikrovaskular, diantaranya retinopati diabetik $8,1 \%$ (16 orang), nefropati diabetik 12,2\% (24 orang), dan neuropati diabetik 6,6\% (13 orang). Tahun 2012 diperoleh total penderita komplikasi kronis sebanyak 148 orang dengan 96 orang penderita komplikasi kronis makrovaskular, diantaranya penyakit jantung koroner $26,9 \%$ (53 orang), penyakit pembuluh darah otak $13,7 \%$ (27 orang), penyakit pembuluh darah perifer 18,8\% (37 orang) dan 123 orang penderita komplikasi kronis mikrovaskular, diantaranya retinopati diabetik 29,4\% (58 orang), nefropati diabetik $30,5 \%$ (60 orang), dan neuropati diabetik 16,8\% (33 orang). 


\section{PEMBAHASAN}

Dari hasil penelitian diketahui bahwa jumlah penderita DM tipe 2 dengan komplikasi kronis dalam waktu 2 tahun adalah 197 orang.Jumlah penderita DM tipe 2 dengan komplikasi kronis meningkat dari tahun 2011 (49 orang) menjadi 148 orang pada tahun 2012 (tabel 2). Dari jumlah tersebut didapatkan penderita komplikasi kronis mikrovaskular tahun 2011-2012 sebanyak 161 orang $(81,7 \%)$, penderita komplikasi kronis makrovaskular sebesar 131 orang $(66,5 \%)$, dan yang memiliki makrovaskular dan mikrovaskular 95 orang $(48,2 \%)$. Hal ini sesuai dengan penelitian sebelumnya di RS Dr. M. Djamil Padang pada tahun 2005 oleh Yulia Darmawi didapatkan jumlah penderita komplikasi kronis mikrovaskular lebih banyak daripada komplikasi kronis makrovaskular, didapatkan komplikasi kronis mikrovaskular sebanyak 121 orang $(73,33 \%)$, penderita komplikasi kronis makrovaskular sebanyak 95 orang $(57,58 \%)$, selanjutnya didapatkan penderita yang memiliki kedua jenis komplikasi sebanyak 51 orang $(30,1 \%)^{5}$

Pada tabel 3 jenis komplikasi kronik terbanyak adalah nefropati diabetik (42,6\%). Kemudian disusul oleh komplikasi retinopati diabetik $(37,6 \%)$, penyakit jantung koroner $(33 \%)$, penyakit pembuluh darah perifer $(30 \%)$, neuropati diabetik $(23,4 \%)$ dan penyakit pembuluh darah otak (19\%). Hal ini sesuai dengan penelitian sebelumnya pada tahun 2010 oleh Ria Amalia di Surabaya yaitu didapatkan komplikasi terbanyak nefropati diabetik $(58,40 \%)$, kemudian disusul dengan komplikasi penyakit pembuluh darah perifer $(37,10 \%)$, retinopati diabetik $(32,10 \%)$, penyakit jantung koroner $(12,70 \%)$, neuropati diabetik $(10,90 \%)$, dan penyakit pembuluh darah otak $(10,40 \%) .{ }^{6}$ Berbeda dengan penelitian yang dilakukan oleh Lia Andriani di RS. Herna Medan pada tahun 2011 kepada penderita diabetes melitu tipe 2 ditemukan insidensi komplikasi kronis terbanyak adalah penyakit pembuluh darah perifer $(26,10 \%)$, kemudian disusul oleh komplikasi nefropati diabetik $(13,4 \%)$, penyakit pembuluh darah otak $(6,7 \%)$, neuropati diabetik $(5,2 \%)$ dan penyakit jantung koroner $(3,7 \%){ }^{7}$ Hal tersebut kemungkinan karena keterbatasan sampel yang digunakan di dalam penelitian, selain itu faktor pengendalian glukosa darah dan faktor risiko hipertensi juga memegang peranan penting dalam terjadinya komplikasi mikrovaskular nefropati diabetik DM tipe $2^{6,7}$

Pada tabel 4 dan 5 dapat diketahui perbedaan insidensi jenis komplikasi kronik DM tipe 2 pada tahun 2011 dengan tahun 2012. Pada tahun 2011 penderita komplikasi kronis makrovaskular sebanyak 35 orang penderita komplikasi kronis makrovaskular, diantaranya penyakit jantung koroner $6,1 \%$ (12 orang), penyakit pembuluh darah otak $5,1 \%$ (10 orang), penyakit pembuluh darah perifer $11,2 \%$ (22 orang), dan 38 orang penderita komplikasi kronis mikrovaskular, diantaranya retinopati diabetik $8,1 \%$ (16 orang), nefropati diabetik 12,2\% (24 orang), dan neuropati diabetik 6,6\% (13 orang). Tahun 2012 diperoleh total penderita komplikasi kronis sebanyak 148 orang dengan 96 orang penderita komplikasi kronis makrovaskular, diantaranya penyakit jantung koroner $26,9 \%$ (53 orang), penyakit pembuluh darah otak $13,7 \%$ (27 orang), penyakit pembuluh darah perifer $18,8 \%$ (37 orang) dan 123 orang penderita komplikasi kronis mikrovaskular, diantaranya retinopati diabetik 29,4\% (58 orang), nefropati diabetik 30,5\% (60 orang), dan neuropati diabetik 16,8\% (33 orang). Hal tersebut disebabkan oleh karena peningkatan yang signifikan pada penderita DM tipe 2 rawat inap di bagian Penyakit Dalam RS. Dr. M. Djamil Padang dari tahun 2011 ke tahun 2012, dapat dipengaruhi oleh pola hidup yang tidak baik seperti kebiasaan mengkonsumsi makanan tinggi lemak dan glukosa, sehingga meningkatkan angka kejadian diabetes melitus tipe 2 beserta komplikasi mikrovaskular dan makrovakular. Hal ini juga didukung oleh pernyataan WHO bahwa angka kejadian DM akan selalu meningkat dari tahun ke tahun dan seterusnya juga akan meningkatkan insidensi jenis komplikasi kronis DM tersebut. ${ }^{1}$

Hal ini sesuai dengan penelitian sebelumnya pada tahun 2005 oleh Yulia Darmawi di Padang bahwa terjadi peningkatan berturut-turut pada penderita komplikasi kronis DM tipe 2 yaitu penyakit jantung koroner meningkat dari tahun 2002 (18,18\%) ke tahun $2003(36,36 \%)$, penyakit pembuluh darah otak meningkat dari tahun 2002 (4,55\%) ke tahun $2003(20,45 \%)$, dan penyakit pembuluh darah perifer meningkat dari tahun $2002(6,82 \%)$ ke tahun 2003 $(15,91 \%) .^{5}$ 
Distribusi frekuensi pada tabel 4 mengenai karakteristik umum penelitian dapat dilihat bahwa penderita perempuan pada komplikasi kronik DM tipe 2 lebih banyak dari pada laki-laki. Hal ini sesuai dengan penelitian sebelumnya di Manado oleh William bahwa DM tipe 2 lebih banyak terjadi pada perempuan daripada laki-laki. Memang tidak terdapat di dalam jurnal bahwa ada keterkaitan jenis kelamin di dalam angka kejadian diabetes melitus maupun komplikasinya, namun sebagian besar peneliti mencantumkan jenis kelamin di dalam kriteria penelitian dan didapatkan hal serupa pada hasil penelitian ini. Pada umumnya, risiko penyakit vaskular pada laki-laki lebih besar daripada perempuan. Namun, pada penyandang diabetes, risiko tersebut menjadi sama antara laki-laki dan perempuan karena peningkatan risiko yang lebih besar pada perempuan sebagai penyandang diabetes. ${ }^{8}$

Tabel distribusi frekuensi 1 juga memperlihatkan komplikasi kronis DM tipe 2 terbanyak pada usia<60 tahun (71\%) baik pada laki-laki (65\%) maupun perempuan (74\%). Hal ini sesuai dengan hasil penelitian sebelumnya pada tahun 2011 di Surabaya tentang gambaran komplikasi kronis DM tipe 2 dan didapatkan penderita terbanyak pada perempuan $(53,40 \%)$ dengan usia 51-60 tahun $(33,5 \%){ }^{6}$

\section{KESIMPULAN}

Insiden komplikasi kronis makrovaskular DM tipe 2 selama 2 tahun tersebut sebanyak 131 (66,5\%) orang, tahun 2011 sebesar $71,4 \%$ terdiri dari: penyakit jantung koroner 6,1\% (12 orang), penyakit pembuluh darah otak $5,1 \%$ (10 orang), penyakit pembuluh darah perifer 11,2\% (22 orang). Tahun 2012 terdiri dari penyakit jantung koroner $26,9 \%$ (53 orang), penyakit pembuluh darah otak 13,7\% (27 orang), penyakit pembuluh darah perifer 18,8\% (37 orang). Komplikasi kronis mikrovaskular: 161 orang $(81,7 \%)$, tahun 2011 sebesar $77,6 \%$ terdiri dari: retinopati diabetik 8,1\% (16 orang), nefropati diabetik 12,2\% (24 orang), dan neuropati diabetik 6,6\% (13 orang). Tahun 2012 sebesar $83,1 \%$ terdiri dari: retinopati diabetik $29,4 \%$ (58 orang), nefropati diabetik 30,5\% (60 orang), dan neuropati diabetik $16,8 \%$ (33 orang).

\section{UCAPAN TERIMA KASIH}

Penelitian ini dapat berlangsung berkat dukungan dari para pembimbing yaitu Prof. Dr. dr. $\mathrm{H}$. Asman Manaf, SpPD-KEMD dan dr. Efrida, SpPK. Ucapan terima kasih juga ditujukan kepada pegawai instalasi rekam medis yang membantu jalannya penelitian ini.

\section{DAFTAR PUSTAKA}

1. WHO. Health topics: diabetes melitus. [internet], 2013. (diunduh 2 Juni 2012). Tersedia dari: URL: HYPERLINKhttp://www.who.int/topics/diabetes me llitus/en/.

2. Yoga T. Prevalensi diabetes melitus. Seminar peringatan Hari Diabetes Sedunia 2009 di Jakarta. Tersedia dari: URL: HYPERLINK http://www. depkes.go.id/index.php/berita/press-release/414tahun-2030-prevalensi-diabetes-melitus-diindonesia-mencapai-213-juta-orang.html

3. PERKENI. Konsensus pengelolaan dan pencegahan diabetes mellitus tipe 2 di Indonesia. 2006 (diunduh 2 Juni 2012). Tersedia dari: URL: HYPERLINK http://www.kedokteran.info/konsen sus-pengelolaan-dan-pencegahan-diabetesmelitus-tipe-2-di-indonesia-2006.html.

4. Price SA, Wilson LM. Patofisiologi konsep klinis proses-proses penyakit. Edisi ke-6. Jakarta: EGC; 2006.

5. Darmawi Y. Gambaran komplikasi makrovaskular penderita diabetes melitus di RSUP M. Djamil tahun 2001-2003. Padang: Universitas Andalas; 2005.

6. Amalia R. Gambaran distribusi komplikasi kronik gangguan vaskuler pada penderita diabetes mellitus tipe 2 di instalasi rawat inap RSUD dr. Soetomo Surabaya Periode waktu 1 April 2010 30 Juni 2010. Surabaya; 2011.

7. Andriani L.Karakteristik penderita diabetes mellitus dengan komplikasi yang dirawat inap di RSU Herna Medan tahun 2009-2010. Medan; 2011.

8. Williams K, Tchernof A, Hunt KJ, Wagenknecht LE, Haffner SM, Sniderman AD. Diabetes, abdominal adiposity, and atherogenic dyslipoproteinemia in women compared with men. Diabetes;57:3289-96. 